SAD / JSR

Sosyoloji Araştırmaları Dergisi / Journal of Sociological Research

Cilt / Volume 20 Say1 / Number 1 (Nisan /April 2017) : (176-200)

\title{
SOUTH AFRICAN PSYCHOLOGICAL WORK ON BOYS, MEN AND MASCULINITIES: TWO DECADES OF MASCULINITY RESEARCH POST FIRST DEMOCRATIC ELECTIONS (1994 - 2011)
}

Cheryl POTGIETER ${ }^{1}$

Hande ESLEN-ZIYA ${ }^{2}$

Tamara SHEFER ${ }^{3}$

\begin{abstract}
The research on masculinities in South Africa has grown rapidly over the last two decades. This paper is an attempt to review of theory and research on masculinities published in South Africa and unpacks the key foci of South African Psychology on masculinities and to analyse the dominant discourses inherent in these work. This paper approaches South African psychology, through the vehicle of the two key journals, the South African Journal of Psychology (SAJP) and Psychology in Society (PINS) published from 1994 to 2011. Our analysis suggests two clear streams of work looking at boys, men and masculinities in South African Psychology. Firstly, there are those that fall into the traditional paradigm of reproducing notions of an essentialised binarism of gender. Secondly, there is the work that focuses on performances of masculinities which draws primarily on current interdisciplinary research generated internationally and locally within the framework of critical men's studies.
\end{abstract}

Key Words: Social Sciences, Psychology, South Africa, Men and Masculinities.

${ }^{1}$ Prof.,University of Kwazulu-Natal, College of Humanities

${ }^{2}$ Assoc. Prof., University of KwaZulu Natal, College of Humanities

${ }^{3}$ Prof., University of the Western Cape, the Faculty of Arts

SAD / JSR

Cilt / Volume 20 Sayı / Number 1 


\section{ÖZ}

Geçtiğimiz son 20 yılda Güney Afrika'da erkek ve erkeklik araştırmaları, hızlı bir şekilde artmıştır. Bizim çalışmamız da işte bu akademik çalışmaları inceleyerek, erkeklik üzerine yazılmış araştırma ve teorilerin analizini yapmak, ve ortaya çıkan belli başlı diskurları saptamayı hedeflemektedir. Bu makale Güney Afrika psikolojisine olan yaklaşımı iki önemli akademik makale aracılığı ile incelemektedir: the South African Journal of Psychology (SAJP) (Güney Afrika Psikoloji Dergisi) ve Psychology in Society (PINS) (Toplumda Psikoloji). 1994 - 2011 yılları arasındaki yayınlarını incelediğimiz bu iki derginin, iki şekilde erkek ve erkeklik kurgusu yarattığı sonucuna vardık. Birinci bulgumuz dergilerde yayınlanan makalelerin geleneksel toplumsal cinsiyet normlarını devam ettirdiği yolundadır. İkinci bulgumuz ise, erkeklik performansları üzerine çalışmaların varlığını saptamaktadır. Bu çalışmalar eleştirel erkeklik çalışmaları ile benzer içeriktedir.

Anahtar Kelimeler: Sosyal Bilimler, Psikoloji, Güney Afrika, Erkek ve Erkeklik. 


\section{INTRODUCTION}

In the early 1990s, as part of the larger imperative of national gender transformation and a growing body of feminist research, a burgeoning field of work on boys, men and masculinities began to emerge in South Africa. It drew on and contributed to the international field of critical men's studies (Morrell, Jewkes \& Lindegger, 2012). This scholarship on masculinities in South Africa was flagged by a range of social sciences edited texts (see for example, Gibson \& Hardon, 2005; Morrell 2001; Ouzgane \& Morrell, 2005; Reid \& Walker, 2005; Richter \& Morrell, 2006; Shefer, Ratele, et al., 2007) and special editions of journals (The Journal of Southern African Studies, 1998; Agenda, 1998). In their overview article in the JPA special edition on masculinities, Shefer, Stevens and Clowes (2010) outline six key areas of research that have emerged as salient in the South African context: fatherhood and men's practices of fathering, male sexuality, male violence, performances of masculinities, particularly among young men, male risk-taking, and the documentation of resistant and alternative masculinities.

A decade later local psychology journals also took up the challenge of theorizing masculinities with two special editions of Psychology in Society (PINS) in 2007 (Eagle \& Hayes, 2007) and 2008 (Shefer, Bowman \& Duncan, 2008) and a special edition of the continental psychology journal, the Journal of Psychology in Africa (JPA) (2010). This scholarship followed on from a small body of earlier feminist scholarship that focused on deconstructing gendered psychology (see for example, Levett \& Kottler, 1998; Macleod, 2006; Potgieter \& de la Rey, 1997; Shefer, Potgieter \& Strebel, 1999). Prior to the development of feminist scholarship in psychology, the focus on gender in South African psychology had for the most part followed the international trend of attempting to prove or disprove gender difference and the application of gender as a variable rather than a critical lens. The lack of a critical and feminist analysis of the psychology of women and men and the conservative function of psychology with respect to reproducing normative gender roles has been well-argued internationally (Connell, 1987; Hare-Mustin \& Maracek, 
1990; Lott, 1990; Morawski, 1990; Unger, 1990) and foregrounded in South African psychology (Macleod, 2006; Shefer, Boonzaier \& Kiguwa, 2006). This paper by focusing on the masculinity research in South Africa post first (1994-2011) democratic elections, is an attempt to review and understand the cultural constructions of masculinities as well as the dominant discourses within the culture that shape such masculinities.

There is little international work in psychology that reflects on the incorporation of the work of masculinities theorists in theorising gender in psychology. However, a recent paper by Mankowski and Maton (2010) provides an international review of work on masculinities in community psychology, including both research and programmatic interventions. They conclude, as has been widely argued by feminist psychologists, that psychological studies continue to study men as generic and not gendered beings (Bohan, 1992; Hare-Mustin \& Marecek, 1990).

While there has been a proliferation of research on boys, men and masculinities in South Africa, which has also been taken up by local psychologists as noted above, there has been little critical review which critically assesses how community psychologists have taken up the focus on men. On the other hand, there has been some critique by local critical and feminist psychologists of contemporary work on masculinities. Macleod (2007) for example criticizes the work of some of the best known local masculinities theorists for falling into 'a phallocentric trap' (p. 7), in particular through conflating women and men into a singular, universal model and concentrating almost exclusively on men and masculinities, thus marginalising women. Similarly, Chadwick and Foster (2007) in their attempt to 'trouble' the widespread assumption that South African masculinities are 'in crisis', argue that the work on masculinities reduces masculinity to an individualised unitary subjectivity and argue for 'a more theoretically nuanced analysis of masculinity which ... recognises the over-determined interpretation of ideology, power relations and socio-material constraints in the reproduction of subjectivity' (p. 27). 
Notwithstanding these critiques of the larger body of work on boys, men and masculinities it is not clear to what extent local psychologists have engaged with the larger feminist project on masculinities as reflected by the international work of critical men's studies. Moreover, an interrogation of the dominant discourses in local psychological literature on boys, men and masculinities has not been undertaken. This article therefore approaches South African psychology, through the vehicle of the two key psychology journals, the South African Journal of Psychology (SAJP) and Psychology in Society (PINS), towards an interrogation of the nature and extent to which local psychology has intersected with critical men's studies. Through an analysis of the two primary national journals, as has been done in international community psychology for example (Mankowski \& Maton, 2010), local psychological work on men and masculinities was interrogated in order to identify possible challenges and gaps with respect to how psychology is currently engaging with international thinking and research on masculinities.

\section{METHODS}

The article draws on the South African Journal of Psychology (SAJP) and Psychology in Society (PINS), as the two key psychology journals that reflect the body of work in South Africa. Past 18 years, using 1994 as a key turning point in South African psychology and as the entry into democracy have been sampled. SAJP has historically been the mainstream journal of psychology in South Africa and PINS has been framed as the voice of critical psychology during and after apartheid (see for example, Hayes, 2010). In general, a shift from the 'marked silence around gender' (Shefer, Van Niekerk, Duncan, de la Rey, 1997, p. 38) in these journals to a greater engagement around issues of gender and gender equality would be evident since 1994. It is assumed then that the scholarship on gender, including work on boys, men and masculinities within psychology would have increased from this date on. This is indeed confirmed by our review of these journals, as a scan of the editions before 1994 shows little research on gender more broadly (also see Shefer, Shabalala \& Townsend, 2004). 
The methodology for the article included generating a list of all the abstracts in these two journals from 1994 to 2011. All articles that specifically discuss boys, men and/or masculinities as a primary or secondary focus were extracted. While a total of 1075 articles in the SAJP and 143 articles in PINS were identified using this method, a total of 30 articles in the SAJP and 19 articles in PINS were engaged with in-depth, as they focused more directly on these issues. In the references* denote articles from the SAJP and ** denote articles from PINS.

The analysis of this paper is guided by an attempt to, firstly, unpack the key foci of South African psychology on masculinities and secondly, to analyse the dominant discourses inherent in this work. Based on this analysis the findings are presented in two thematic sections below, followed by critical reflections on how masculinities have been researched by contemporary psychology in South Africa. While the articles are reviewed regardless of which journal they are from, these are clearly differentiated in the reference list.

It is important to note that there is also a wide range of articles that focus on women and women's experience of abuse or subordination by men, but do not always directly focus on men (although some of these studies include both male and female participants). Many of these articles highlight important understandings of men and male practices of masculinity (for example, Wood and Foster, 1995; Shefer, Strebel and Foster, 2000; Lesch and Kruger 2004; Hoosen and Collins, 2004; Van Wijk, Finchilescu \& Tredoux, 2009); however for the most part these are not extracted for analysis or problematised within a masculinities framework. For example a study by Braine, Bless and Fox (1995) provides some interesting insights into how male students continue to subscribe to a 'blaming' discourse in which women are seen as contributing to their own sexual harassment. However the article misses the opportunity to contribute to both theoretical and intervention-based development through a more critical and deeper analysis of the role of hegemonic masculinities in re-inscribing normative notions of gender which serve to legitimize practices of sexual harassment. We have therefore not explored this body of work which potentially offers insight 
into contemporary South African masculinities, but largely misses the opportunity to do so and focus instead on only those that either directly focus on boys, men and masculinities or at least include this as a clear secondary focus.

The findings are presented in two main sections that in our analysis speak to the two primary philosophical frameworks in which issues of boys, men and masculinities have been dealt with in these two journals. Firstly, we engage with the articles that primarily present research that explores how men are different psychologically from women and have different mental health issues to women; secondly, we present a review of those articles which speak to socially constructed performances and representations of masculinities.

\section{Men as psychologically different from women}

As might be expected from a psychological journal, a key area of work on men and masculinities in the SAJP in particular is one that is located in traditional empiricist Social Psychology. This work, which has historically been criticized for reproducing and rationalizing gender differences, looks at different psychological issues, such as 'psychological well-being' or 'coping' as a manager, and is concerned with either proving gender difference or documenting particularities for men. Thus for example Roothman et al (2003) conduct a study that aimed to 'determine whether men and women differed with regard to aspect of psychological well-being' (p. 212). Similarly, applying the Bem Scale, May and Spangenberg (1997) assess the relationship between sex-role orientation as defined by this scale, and coping ability in men with a managerial orientation, and conclude that both androgyny and masculinity assist with coping.

A range of other studies in a similar vein attempt to assess psychological differences between men and women, generally applying gender as a variable in exploring certain disorders, performances and characteristics, in areas such as test anxiety and academic achievement (Huysamen \& Roozendaal, 1999; 
Mwamwenda, 1994), perfectionism among young men (Fry, Greenop, Turnball \& Bowman, 2009),

Seasonal Affective Disorder (Kane \& Lowis, 1999), and perception of emotion and functional hemispheric asymmetry (Fourie \& Stuart, 1996).

These articles tend to assume a universalised, essential masculinity and reproduce static, binaristic notions of an inherent and given gender identity that has been destabilised by feminist and queer theorists internationally (see the foundational work of Butler, 2004; 2000; 1993 and 1990) and also been criticized in the work of local psychologists (Potgieter \& de la Rey, 1997; Shefer, Potgieter \& Strebel, 1999; Shefer, 2001; Shefer, Boonzaier \& Kiguwa, 2006). Bem's model, for example, has been criticized for reproducing notions of a unitary self (Butler, 1990) and ultimately rationalising gender categorisation, rather than challenging it (Unger, 1990; Wetherell, 1986). Furthermore, the model of androgyny is ironically (and predictably) biased towards 'masculinity', with masculinity scores strongly predictive of androgynous behaviour, and the very construct itself based on individualist, male-centred values (such as independence, self-containment, instrumentality) (Morawski, 1990). Similarly most of these articles also reproduce notions that traditionally masculine characteristics are associated with psychological well-being, while traditionally female characteristics are associated with mental illness. The shortcomings identified by more contemporary feminist critiques of models such as Bem's have therefore been mostly ignored.

Within the category of articles focusing on men as different, there are also a number of articles that address issues of mental health and masculinity. Strumper and Bands (1996), for example, examine stress among Anglican priests and Edwards and Moldan (2004) research bulimia among Black men. While they may identify their sample as men, the category is not recognised as having any theoretical value and the centrality of hegemonic masculinity in shaping these challenges is thus not interrogated. This theoretical oversight may be seen as a missed opportunity to incorporate masculinities studies in explaining certain psychological challenges for men, as a gendered group. The consequence of this is evident in an article by Freeman and 
Szabo (2005) who aim to determine whether the clinical presentation of hospitalised male patients in South Africa is congruent with that documented in the international literature. There was arguably much potential in this article to draw on the body of work of masculinities studies to elaborate on how dominant masculinities in this subculture might have framed this particular condition and provide far more insight. However the authors do not go beyond more traditional variables, such as socio-economic status, to define the profile of men who present with this condition. Moreover the article concludes by stating that 'this is an area that requires substantial future research, specifically regarding the alignment of the treatment and diagnosis guidelines for males, as opposed to females' (p. 6220). In this way the article, while an important exposure of a marginalized condition for men, stereotyped as a feminine preserve, inadvertently serves to reiterate and reinforce the gender difference discourse.

While this imperative to prove (or disprove) gender differences emerges as a dominant theme, notably, there is also a marginal attempt to deconstruct the dominant binaristic approach to gender represented in these journals. Thus, as early as 1995 Macleod criticizes the way in which gender differences in mathematics performance in the classroom are assumed in dominant educational psychological discourse. She argues that 'we are able to view the notion of gender differences as something that is linguistically rather than intrinsically real' (1995, p. 23).

\section{Social constructions and performances of masculinities}

Some of the SAJP articles on masculinities and most of the articles in PINS elaborate on social constructions, practices and representations of masculinities. These articles are generally well-versed in critical men's studies, drawing on key theoretical concepts like Connell's (2005) hegemonic masculinities, researching boys, men and masculinities as socially constructed. These articles mostly address the key national challenges of HIV and gender-based violence and focus on male sexuality and male perpetrators across different contexts which are significant in shaping dominant masculinities, such as the military and 
schools. Most of these studies utilise qualitative methodologies and are clearly located in poststructuralist critical psychological frameworks that draw on discourse analysis and feminist theory.

Earlier studies tended to focus on narratives of men, such as the study by Kaminer and Dixon (1995) that looks at a group of male university graduates' discussions while in a bar, identifying dominant discourses of masculinity and gender evident in participants' talk. Similarly, Harris, Lea and Foster (1995) explored how gender is constructed by a men's only group. Both studies illustrate dominant discourses in which gender is naturalised or normative, in both cases reproducing a notion of gender difference as inevitable and determined. Reflecting the political shift to focus on women characterizing the early 1990s postapartheid period of transformation, both these sets of authors focus on illustrating how these discourses are problematic for women since they rationalize and serve to excuse problematic masculinities and practices, including male violence against women. However, arguably, they both fail to unpack how these may be problematic for men and boys, nor do they explore the way in which these discourses shape dominant forms of masculinity and male performance. Nonetheless, studies like these that analyze men's talk towards identifying dominant narratives on gender represented an important shift from an assumption of unitary, essentialised gender towards social constructionist accounts that understand the power of language in framing subjectivities and performance.

Similarly, a number of articles in this sub-theme document the dialogical construction of gender, exploring constructions of masculinities and male sexualities through discourse analysis of talk or text. Articles such as Kottler and Swartz's (1995) analysis of a conversation between a man and a woman discussing the effect of 'wolf-whistles' on women shows the fluidity of gender and its socially and dialogically constructed nature, illustrating in a concrete example how men and women may take up different and shifting gender normative positions in dialogue with each other. Schneider, Cockcroft and Hook (2008) look at the 
construction of male sexuality in the South African Men's Health magazine, showing that the texts use male sexual performance as a yardstick for assessing successful masculinity.

While the male sexual drive discourse has been well documented as dominant in the construction of hegemonic masculinities in South Africa, importantly, this study foregrounds the presence of male anxieties about sexual performance. Similarly Gibbs and Jobson (2011), analyzing narratives of masculinity in the media, explore their implications for men's HIV-related health behaviour, highlighting the way in which the media reproduces and reinforces dominant versions of masculinity, and fails to offer alternative narratives on being a man. In a similar vein Dewing and Foster's (2007) study explores men's narratives on the body and appearance in constructing their masculinity. Participants clearly took an interest in their bodies and appearance, yet they distanced themselves from the emerging 'metrosexual' discourses represented in magazines like Men's Health, subscribing rather to more conventional notions of men as uninterested in beauty and body that are still associated with femininity. Importantly, these studies on the media and narrative responses to the media highlight the way in which the media shapes dominant constructions of masculinity.

A range of studies focus on performances of masculinities, based on empirical data collected in local communities. Mostly these studies foreground the multiplicity and shifting practices of being a boy and a man, particularly within the context of male sexuality and the imperative of challenging HIV/AIDS. For example, Blackbeard and Lindegger (2007) studied male identity 'positions' among a group of young men, foregrounding the way in which masculinities are shaped in particular locations and contexts, such as schools, sports, family and male peer group through hegemonic masculine performances such as toughness, invulnerability, risk-taking (substance use) and heterosexual sexuality. In a similar study on the construction of young township masculinities, Langa (2008) highlighted the challenges, costs and sacrifices involved in young men resisting hegemonic masculinities.

$\mathrm{SAD} / \mathrm{JSR}$

Cilt / Volume 20 Say1 / Number 1 
Studies on performances of masculinity foreground the way in which achieving masculinity is a constant struggle, not an achieved end-point, but involving continuous work to maintain a sense of successful masculinity. Thus Davies and Eagle's (2007) study on male adolescent peer counsellors flagged the anxiety associated with shifting masculinities and in particular, the challenges involved in stepping outside of traditional male roles and occupations, such as care work, in negotiating one's masculine identity, Joseph and Lindegger (2007) look at performances of masculinity among adolescent boys who are visually impaired and observe that the anxiety relates to fears of not living up to expected performances of masculinity among participants, causing them to adopt novel strategies to achieve practices of hegemonic masculinity at possible cost to their health and well-being. Some studies illustrate how challenges in achieving hegemonic masculinity are also linked to changes in the post-apartheid context and the impact of HIV. Examples include a study on ex-combatants, which shows how participants struggled to negotiate a new form of identity post-apartheid. Mfecane's (2008) this article provides a complex account of how men's lives shift following their diagnosis of HIV and how they struggle to reinstate a sense of positive masculinity given the way in which illness and treatment undermine their ability to perform in dominant forms of successful masculinity such as being a breadwinner and being (hetero)sexually active. Continuities are also illustrated in articles such as Oxlund's (2008) study of contemporary student politics on a South African campus, which shows how these are shaped by historical patterns of male dominance in the struggle against apartheid.

Within the focus on male performance a number of articles highlight the link between dominant forms of masculinity and violent practices, such as Favell (1998) and Boonzaier and de la Rey's (2004) studies. The latter provides a valuable analysis of the construction of masculinity as authoritative and femininity as subordinate and submissive. de la Harpe and Boonzaier's (2011) article on women's experiences of male intervention groups, while focusing only on women, provides valuable insight into the impact of such 
interventions on men. The data show how these interventions may inadvertently reproduce new forms of male abuse of women, as such men learn to shape their violence in more strategic ways that will be less visible publically, yet do not necessarily shift the experience for women. Within this theme a lone article on gay male relationships (Shefer \& Henderson, 2008) highlights how violence between men is linked to the dominance of a heterosexual model of relationships that impacts on how some gay men practice their relationships and intersects with other forms of inequality including class and 'race'.

Stimulated by the parallel imperative to halt HIV, and linked to the larger proliferation of research on sexualities in the light of HIV, a range of articles speak to male performances of sexuality within a framework of HIV and sexual risk-taking, linking HIV risk with hegemonic masculinities and male dominance in sexuality that are also shaped by the historical material conditions of South African apartheid and colonisation (Macheke and Campbell, 1998, Mankayi, 2008; Strebel \& Lindegger, 1998; Shefer, Strebel \& Foster, 2000). These articles also foreground the importance of local context such as Cooper's (2009) study of a group of young men awaiting trial on the Cape Flats, who position themselves in relation to forms of hegemonic masculinity, foregrounding the key role of 'local language and description of practices and rituals' in shaping masculinities (Cooper, 2009: p. 1).

Some studies also illustrate men's resistance to hegemonic masculinity through alternative performances of masculinity, for example Nichols and Foster (2005) who illustrated how a group of men use tattooing, body piercing, long hair and androgynous 'gothic' style dress as a tool to rebel against the hegemonic order and norms of masculinity.

While many of the articles that speak to the performance of masculinities emerge from qualitative, social constructionist methodologies, some also make use of more traditional quantitative approaches, such as Luyt and Foster's (2001) study on hegemonic masculinities in gang culture, which provides empirical 
evidence of the importance of male toughness, success and control in participants' constructions of themselves, complemented by qualitative data that showed how gang activity was perceived as a means to achieve access to such hegemonic masculine values.

\section{CONCLUDING DISCUSSION}

Our review foregrounds two clear streams of work looking at boys, men and masculinities in South African social sciences as articulated in the two national journals, the SAJP and PINS. Firstly, there are those that fall into the traditional paradigm of reproducing notions of an essentialised binarism of gender in which masculinity and femininity are presumed to reside in subjects in a unitary manner. Much of this work, even when well meaning tends to legitimise gender inequalities. Secondly, there is the work that focuses on performances of masculinities which draws primarily on current interdisciplinary research generated internationally and locally within the framework of critical men's studies. Most of the content in such studies reflects national imperatives and mirrors the six key areas of research that are salient in the field of masculinities research in South African as outlined by Shefer, Stevens and Clowes (2010) and elaborated earlier.

While this work has generated some valuable material for the larger project of bringing a gendered lens to boys, men and masculinities, it is also evident that much of it has tended to focus on more sociological and discursive accounts of masculinities even while drawing on subjective narratives. A concern with the more subjective level of gendered performance, for example, why certain boys and men may draw on alternative discourses on masculinity, is not well represented. Arguably there is a place for Psychology to bring in more of its own expertise in studying boys, men and masculinities. There is very little work that draws on critical Psychology, for example, the work of psychoanalytic discourse analysts. At risk of setting up a social-psychological binarism, which is not intended, the role of the subjective in negotiating dominant discourses may be an important pursuit for critical psychologists in this field. 
It is further notable for a psychology journal that within this broad theme of men's psychology, there are few articles in this time frame that deal with mental health issues and challenges facing men. The lack of work on male mental ill health may be understood as reproducing the gendered stereotype in which women are associated with pathology and madness (Chesler, 1972); as argued earlier, traditionally male characteristics and masculinity in general are associated with social success, health and well-being. This silence may also reflect the larger gender binarism in which masculinity is disassociated from the body and divorced from health care practices. Overall, the research that dealt with mental health issues arguably failed to generate an understanding of the anchoring role that masculinities may play in shaping men's engagement with their health and well-being, or the negative impact of hegemonic masculinities on boys and men's well-being.

Linked to this gap is evidence that the majority of articles focus more on men as agents of privilege and power, then the negative impact of masculinities on men and boys. The articles that draw on critical men's studies arguably foreground a concern to highlight women's oppression and foreground male privilege, reflecting a similar theme highlighted in Mankowski and Maton's (2010) international review of community psychology. The latter argue that work on masculinities has focused more on male privilege than on 'damage', thus invisibilising the way in which dominant forms of masculinity may impact negatively on boys and men themselves. We concur that this lack of recognition of the negative impact of dominant forms of masculinities on men and boys' mental health, for example, is a shortcoming and a missed opportunity for psychologists to make a contribution to critical men's studies.

Considering the high rate of mortality among young, poor men in South Africa that Ratele (2008) has alerted us to, it is notable that there is a silence on the appreciation of the obviously negative impact of hegemonic forms of masculinity on boys and men themselves. Thus, the way in which dominant frameworks of being men impacts negatively on boys and men's well-being, both emotionally and 
physically, clearly a concern for Psychology as a health-based discipline and practice, is noticeably missing.

Psychologists are arguably well placed to contribute to the challenges of gender transformation by studying the way in which hegemonic discourses on masculinity shape the subjective experiences and undermine the well-being of not only girls and women, but also boys and men in diverse South African contexts. 


\section{ÖZET}

Yaptığımız bu çalışmada iki şekilde erkek ve erkeklik kurgusu yarattı̆̆ sonucuna vardık. Birinci bulgumuz dergilerde yayınlanan makalelerin geleneksel toplumsal cinsiyet normlarını devam ettirdiği yolunda idi. Bu çalışmalara göre hem erkeklikler hem de kadınlıklar üniter bir şekilde ele alınmaktaydılar ve neredeyse toplumsal cinsiyet eşitsizliklerini haklı çıkartıyorlardı. İkinci bulgumuz ise, erkeklik performansları üzerine çalışmaların varlığını saptıyordu. Bu çalışmalar eleştirel erkeklik çalışmaları ile benzer içerikteydiler. İkinci bulgumuza ait makaleler erkek olmak ve erkeklikler çalışmalarına katkı sağlayacak çalışmalardı. Bunlardan bazıları toplumsal cinsiyet performanslarına eğilmekteydi ve sosyolojik ve sosyal psikolojik bakış açısı ile ele almaktaydılar. Bu bağlamda bireysel ve psikolojik açıdan da erkek olmak ve erkeklik kavramlarının incelenmesi gerektiğini vurgulayabiliriz. Aynı zamanda erkeklerin ruhsal rahatsızlıklarını ele alan çok az sayıda yayın olduğu da bulgularımız arasındadır. Bu ise kadınların daha fazla patoloji ve akıl hastalıkları ile ilişkilendirilmesine ve toplumsal cinsiyet steoritiplerinin oluşmasına sebep olmaktadır. 


\section{REFERENCES ${ }^{4}$}

"Blackbeard, D. \& Lindegger, G. (2007). Building a Wall Around Themselves': Exploring Adolescent Masculinity and Abjection with Photo-Biographical Research. South African Journal of Psychology, 37 (1), 25-46.

Bohan, J.S. (Ed.) (1992). Seldom Seen, Rarely Heard: Women's Place in Psychology. Boulder, Colorado: Westview Press.

"Boonzaier, F. \& de la Rey, C. (2004). Woman Abuse: The Construction of Gender in Women and Men's Narratives of Violence. South African Journal of Psychology, 34 (3), 443-463.

"Braine, J.D., \& Bless, C. \& Fox, P.M.C. (1995). How Do Students Perceive Sexual Harassment?: An Investigation on The University of Natal, Pietermaritzburg Campus. South African Journal of Psychology, 25 (3), 140-149.

Butler, J. (1990). Gender Trouble: Feminism and the Subversion of Gender. London: Routledge.

Butler, J. (1993). Bodies That Matter: On The Discursive Limits Of Sex. London: Routledge.

Butler, J. (1994). Against Proper Objects, Differences. A Journal of Feminist Cultural Studies, 6 (2\&3), 126.

Butler, J. (2000). Critically Queer, in: P. Du Gay, J. Evans \& P. Redman (Eds) Identity: A Reader. London: Sage/Open University Press.

Butler, J. (2004). Gender Undone. Boca Raton, FL: Routledge Taylor and Francis.

${ }^{* *}$ Chadwick, R. \& Foster, D. (2007). In Transition But Never Undone?: Contesting Masculinity. Psychology in Society, 35, 27-37.

Chesler, P. (1972). Women and Madness. Garden City, New York: Doubleday.

\footnotetext{
$4 *$ denotes articles from the South African Journal of Psychology (SAJP)

** denotes articles from Psychology in Society (PINS)
}

$\mathrm{SAD} / \mathrm{JSR}$

Cilt / Volume 20 Sayı / Number 1 
Connell, R.W. (1987). Gender and Power. Stanford, Ca: Stanford University Press.

Connell, R.W. (2005). Masculinities ( $\left.2^{\text {nd }} e d.\right)$. California: University of California Press.

**Cooper, A. (2009). "Gevaarlike Transitions": Negotiating Hegemonic Masculinity and Rites of Passage Amongst Coloured Boys Awaiting Trial on the Cape Flats. Psychology in Society, 37, 1 - 17.

Cooper, S., Nicholas, L., Seedat, M. \& Statman, J. M. (1990). Psychology and Apartheid: The Struggle for Psychology in South Africa. In L. Nicholas \& S. Cooper (Eds.), Psychology and Apartheid. Johannesburg: Vision/Madiba Press.

*Corbet-Owen, C. (2003). Women's Perceptions of Partner Support in the Context of Pregnancy Loss(es). South African Journal of Psychology, 33 (1), 19-27.

** Davies, \& Eagle, G. (2007). "Nowadays They Say ...": Adolescent Peer Counsellors' Appreciation of Changes in the Construction of Masculinity. Psychology in Society, 35, 53-72.

"De La Harpe, K., \& Boonzaier, F. (2011). Women's Experiences of an Intervention for Violent Men. South African Journal of Psychology, 41 (2), 147-156.

** Dewing, S. \& Foster, D. (2007). Men's Body Related Practices and Meanings of Masculinity. Psychology in Society, 35, 38 - 52.

${ }^{* *}$ Eagle, G. \& Hayes, G. (2007). Masculinity in Transition - 1. Psychology in Society, 35, 1-3.

"Edwards, D., \& Moldan, S. (2004). Bulimic Pathology in Black Students in South Africa: Some Unexpected Findings. South African Journal of Psychology, 34 (2), 191-205.

**Favell, A. M. (1998). Notes on the Intervention of Men Who Use Violence Against Intimates. Psychology in Society, 23, 35 - 51.

"Fourie, J.C. \& Stuart, A. (1996). The Role of Temperament and Gender in Functional Hemispheric Asymmetry and the Perception of Emotion. South African Journal of Psychology, 26 (1), 52-62.

"Freeman, A.C. \& Szabo, C.P. (2005). Eating Disorders in South African Males: A Review of the Clinical Presentation of Hospitalized Patients. South African Journal of Psychology, 35 (4), 601-622.

$\mathrm{SAD} / \mathrm{JSR}$

Cilt / Volume 20 Say1 / Number 1 
**Frizelle, K. \& Kell, G. (2010). A Contextual Account of Motherhood. Psychology in Society, 39, 26 - 44.

"Fry, J., Greenop, K., Turnbull, O. \& Bowman, C. (2009). The Effect of Education and Gender on EmotionBased Decision-Making. South African Journal of Psychology, 39 (1), 122-132.

*Gibbs, A. \& Jobson, G. (2011). Narratives of Masculinity in the Daily Sun: Implications for HIV Risk and Prevention. South African Journal of Psychology, 41 (2), 173-186.

Gibson, D. \& Hardon, A. (2005). Rethinking Masculinities, Violence and AIDS. Amsterdam: Het Spinhuis.

Hare-Mustin, R. \& Marecek, J. (Eds.) (1990). Making a Difference: Psychology and the Construction of Gender. New Haven, CT: Yale University Press.

"Harris, E., Lea, S. \& Foster, D. (1995). The Construction of Gender: An Analysis of Men's Talk on Gender. South African Journal of Psychology, 25 (3), 175-183.

${ }^{* *}$ Hayes, G. (2010). Siyanda Ndlovu. Psychology in Society, 39, 54 - 55.

*Henderson, N. \& Shefer, T. (2008). Practices of Power and Abuse in Gay Male Relationships: An Exploratory Case Study of a Young, Xhosa-Speaking Man in the Western Cape, South Africa. South African Journal of Psychology, 38(1), 1-20.

"Hoosen, S. \& Collins, A. (2004). Sex, Sexuality and Sickness: Discourses of Gender and HIV / AIDS among Kwazulu-Natal Women. South African Journal of Psychology, 34 (3), 487- 505.

"Huysamen, G.K. \& Roozendaal, L.A. (1999). Curricular Choice and the Differential Prediction of the Tertiary-Academic Performance of Men and Women. South African Journal of Psychology, 29 (2), $87-93$.

** Joseph, L. \& Lindegger, G. (2007). The Construction of Adolescent Masculinity by Visually Impaired Adolescents. Psychology in Society, 35, 73 - 92.

*Kaminer, D. \& Dixon, J. (1995). The Reproduction of Masculinity: A Discourse Analysis of Men's Drinking Talk. South African Journal of Psychology, 25 (3), 168-174.

"Kane, A. \& Lowis, M.J. (1999). Seasonal Affective Disorder and Personality, Age, and Gender. South African Journal of Psychology, 29 (3), 124-127. 
"Kottler, A. \& Swartz, S. (1995). Talking About Wolf-Whistles: Negotiating Gender Positions in Conversation. South African Journal of Psychology, 25 (3), 184-190.

**Langa, M. (2008). Using Photo-Narratives to Explore the Construction of Young Masculinities. Psychology in Society, 36, 6 - 23.

"Lesch, E. \& Kruger, L.M. (2004). Reflections on the Sexual Agency Of Young Women in a Low-Income Rural South African Community. South African Journal of Psychology, 34 (3), 464-486.

Levett, A. \& Kottler, A. (1998). Through A Lens, Darkly. In Burman, E. (ed.), Deconstructing Feminist Psychology, 184-205. London: Sage.

Lott, B. (1990). Dual Natures or Learned Behaviour: The Challenges to Feminist Psychology. In R. T. Hare-Mustin \& J. Maracek (Eds), Making a difference: psychology and the construction of gender (pp. 65-101). New Haven: Yale University Press.

**Louw, J. (1992). "To Rule and Own, or To Live Like Shy Deer": The Dilemmas of a Profession. Psychology in Society, 16, 49-60.

"Luyt, R. \& Foster, D. (2001). Hegemonic Masculine Conceptualisation in Gang Culture. South African Journal of Psychology, 31 (3), 1-11.

"Macheke, C. \& Campbell, C. (1998). Perceptions of HIV/AIDS on a Johannesburg Gold Mine. South African Journal of Psychology, 28 (3), 146-153.

"Macleod, C. (1995). Gender Differences in Mathematics: A Discourse Analysis. South African Journal of Psychology, 25 (3), 191-202.

Macleod, C. (2006). Radical Plural Feminisms and Emancipatory Practice in Post-Apartheid South Africa. Theory \& Psychology, 16, 367-389.

**Macleod, C. (2007). The Risk Of Phallocentrism in Masculinities Studies: How a Revision of the Concept of Patriarchy Might Help. Psychology in Society, 35, 4-14.

**Mankayi, N. (2008). Masculinity, Sexuality and the Body of Male Soldiers. Psychology in Society, 36, 24 $-44$. 
Mankowski, E.S. \& Maton, K.I. (2010). A Community Psychology of Men and Masculinity: Historical and Conceptual Review. American Journal of Community Psychology, 45, 73-86.

"May, A. \& Spangenberg, J.J. (1997). Androgyny and Coping in Men with a Managerial Orientation. South African Journal of Psychology, 27 (4), 244-249.

**Mfecane, S. (2008). Living With HIV as A Man: Implications for Masculinity. Psychology in Society, 36, $45-60$.

Morawski, J.G. (1990). Practising Feminisms, Reconstructing Psychology: Notes on a Liminal Science. United States of America: The University of Michigan Press.

Morrell, R. (2001). From Boys to Gentlemen: Settler Masculinity in Colonial Natal, 1880-1920. Pretoria: UNISA Press.

Morrell, R., Jewkes, R. \& Lindegger, G. (2012). Hegemonic Masculinity/Masculinities in South Africa: Culture, Power and Gender Politics. Men and Masculinities, 15(1) 11-30.

Mwamwenda, T.S. (1994). Test Anxiety and Academic Achievement among South African University Students. Psychological Reports: 75, 1593-1594.

Nicholas, L. (1990). The Response of South African Professional Psychology Associations to Apartheid. In L. Nicholas, S. Cooper (Eds.), Psychology and Apartheid. Johannesburg: Vision/Madiba Press.

Nicholas, L. (1993). Psychology in South Africa: The Need for an Openly Politically Contextualised Discipline. In L. Nicholas (Ed.), Psychology and Oppression: Critiques and Proposals. Johannesburg: Skotaville.

**Nichols, H. \& Foster, D. (2005). Embodied Identities and Positional Choices: How Tattoos Construct Identity and Negotiate a Tattooed Status Within Society. Psychology in Society, 32, 1 - 23.

"Oosthuizen, C. M. \& Wissing, M. P. (2005). Prevalence of Violence against Women: Distress, Coping and Psychological Well-Being. Surviving the Fire? South African Journal of Psychology, 35 (4), $637-$ 656.

$\mathrm{SAD} / \mathrm{JSR}$

Cilt / Volume 20 Say1 / Number 1 
Ouzgane, L. and Morrell, R. (Eds/) (2005). African Masculinities: Men in Africa from the Late Nineteenth Century to the Present. Pietermaritzburg / New York: University of KwaZulu-Natal Press / Palgrave Macmillan.

** Oxlund, B. (2008). Masculinities in Student Politics: Gendered Discourses of Struggle and Liberation at the University of Limpopo. Psychology in Society, 36, 60 - 70.

Potgieter, C. \& de la Rey, C. (1997). Gender and Race: Whereto Psychology in South Africa? Feminism and Psychology, 7, 138-142.

"Pretorius, H. G. \& Botha, S.A. (2009). The Cycle of Violence and Abuse in Women Who Kill an Intimate Male Partner: A Biographical Profile. South African Journal of Psychology, 39 (2), 242-252.

Ratele, K. (2008). Masculinity and Male Mortality in South Africa. African Safety Promotion: A Journal of Injury and Violence Prevention, 6(2), 19-41.

Reid, G. and Walker, L. (2005). Masculinities in Question. Inn Reid, G and Walker, L (eds), Men Behaving Differently: South African Men Since 1994. Cape Town: Double Storey Books.

Richter, L. \& Morrell, R. (2006). Men and Fatherhood in South Africa. Cape Town: Richter \& Morrell, 2006.

"Rohleder, P. \& Gibson, K. (2006). We Are Not Fresh': HIV-Positive Women Talk of Their Experience of Living with Their 'Spoiled Identity'. South African Journal of Psychology, 36 (1), 25-44.

"Roothman, B., Kirsten, D. K. \& Wissing, M. P. (2003). Gender Differences in Aspects of Psychological Well-Being. South African Journal of Psychology, 33 (4), 212-218.

"Schneider, V., Cockcroft, K. \& Hook, D. (2008). The Fallible Phallus: A Discourse Analysis of Male Sexuality in a South African Men's Interest Magazine. South African Journal of Psychology, 38 (1), 136-151.

Seedat, M. (1990). Programmes, Trends and Silences in South African Psychology. In L. Nicholas \& S. Cooper (Eds.), Psychology and Apartheid. Johannesburg: Vision/Madiba Press.

Seedat, M. (1992). Topics, Trends and Silences in South African Psychology 1948-1988. Unpublished doctoral dissertation, University of the Western Cape.

$\mathrm{SAD} / \mathrm{JSR}$

Cilt / Volume 20 Say1 / Number 1 
${ }^{* *}$ Shefer, T. (2001). Ordering Gender: Revisiting the Role of Psychology. Psychology in Society, 27, 34 45.

"Shefer \& Henderson, (2008). Practices of Power and Abuse in Gay Male Relationships: An Exploratory Case Study of a Young, Isixhosa-Speaking Man in the Western Cape, South Africa. South African Journal of Psychology, 38 (1), 1-20.

Shefer, T., Boonzaaier, F. \& Kiguwa, P. (Eds.) (2006). The Gender of Psychology. Cape Town: Juta.

${ }^{* *}$ Shefer, T., Bowman, B. \& Duncan, N. (2008). Masculinities in Crisis: Volume Two, Psychology in Society, 36.

Shefer, T., Ratele, K., Strebel, A., Shabalala, N. \& Buikema, R. (Eds.) (2007). From Boys to Men: Social Constructions of Masculinity in Contemporary Society. Cape Town: UCT Press.

Shefer, T., Stevens, G. \& Clowes, L. (2010). The Social Construction of Masculinities in Africa. Journal of Psychology in Africa, 20(4).

"Shefer T., Strebel A. \& Foster D. (2000). So Women Have To Submit To That... Discourses of Power and Violence in Student's Talk on Heterosexual Negotiation. South African Journal of Psychology, 30 (2), 11-19.

"Shefer, T., Shabalala, N. \& Townsend, L. (2004). Women and Authorship in Post-Apartheid Psychology. South African Journal of Psychology, 34, 576-594.

${ }^{* *}$ Shefer, T., van Niekerk, A., Duncan, N. \& de la Rey, C. (1997). Challenging Authorship and Authority in Psychology: A Publishing Initiative. Psychology in Society, 22, 37 - 46.

Shefer, T., Potgieter, C. \& Strebel, A. (1999). Teaching Gender in Psychology at a South African University. Feminism and Psychology, 9(2), 127-133.

${ }^{* *}$ Strebel, A. \& Lindegger G. (1998). Power and Responsibility: Shifting Discourses of Gender and HIV/AIDS. Psychology in Society, 24, 4 - 16.

"Strumpfer, D.J.W. \& Bands, J. (1996). Stress Among Clergy: An Exploratory Study on South African Anglican Priests. South African Journal of Psychology, 26 (2), 67-75. 
Unger, R.K. (1990). Imperfect Reflections of Reality: Psychology Constructs Gender. In R.T. Hare-Mustin \& J. Maracek (Eds), Making a Difference: Psychology and the Construction of Gender (pp. 102149). New Haven: Yale University Press.

${ }^{*}$ Van Wijk, C., Finchilescu, G. \& Tredoux, C. (2009). Sexual Harassment of Women in the South African Navy. South African Journal of Psychology, 39 (2), 169-183.

Vogelman, L. (1986). Apartheid and Mental Halth. Apartheid and Mental Health. First national OASSSA conference proceedings. Johannesburg: OASSSA.

Wetherell, M. (1986). Linguistic Repertoires and Literary Criticism. New Directions for a Social Psychology of Gender. In S.Wilkinson (Ed), Feminist Social Psychology Developing Theory and Practice, 77-95. Philadelphia: Open University Press.

"Wilson, T. \& Strebel, A. (2004). Psychiatric Discourses of Woman Abuse. South African Journal of Psychology, 34 (3), 421-442.

**Womersley, G. \& Maw, A. (2009). Contextualising the Experiences of South African Women in the Immediate Aftermath of Rape. Psychology in Society, 38, 40 - 60.

*Wood, C. \& Foster, D. (1995). "Being the Type of Lover..." It: Gender-Differentiated Reasons for NonUse of Condoms by Sexually Active Heterosexual Students. Psychology in Society, 20, 13 - 35. 